\title{
Scientific Drilling in the East African Rift Lakes: A Strategic Planning Workshop
}

\author{
by James M. Russell, Andrew S. Cohen, Thomas C. Johnson, and \\ Christopher A. Scholz
}

doi:10.2204/iodp.sd.14.08.2012

\section{Introduction and Key Science Themes}

The East African Rift lakes offer unparalleled opportunities to investigate fundamental climate, environmental, biological, and geological processes through deep coring into the lake bed. Their sediments hold signals of the evolution of tropical rainfall, temperatures, and winds across $20^{\circ}$ of latitude on both sides of the equator from the Miocene to the present. Fossil material in these basins chronicles the development of the East African landscapes in which our own species evolved, and records the explosive evolutionary radiation of literally thousands of species of fish, snails, and other aquatic organisms endemic to East Africa's lakes. Drilling these sediments will also provide insights into the tectonic processes that shape the largest active continental rift system on Earth today.

The past decade has witnessed major advances in our efforts to obtain long climate records from the East African lakes, highlighted by the successful scientific drilling of Lake Malawi in 2005 (Scholz et al., 2007). Since 2005, newly acquired and ongoing geophysical surveys by industrial and academic scientists have provided us with much of the requisite site survey information to propose scientific drilling projects in some of the premier target lakes in East Africa, most notably Lake Turkana, Lake Albert, and Lake Tanganyika (Fig. 1). To strategically plan for the next decade of scientific drilling in East Africa's lakes, the U.S. National
Science Foundation (NSF) and Past Global Changes (PAGES) project sponsored "Continental Drilling in the East African Rift Lakes", a workshop attended by thirty-six African, European, and U.S. scientists and hosted by Brown University in Providence, Rhode Island, U.S.A. on 14-16 November 2011.

Recent years have witnessed significant developments in multidisciplinary sciences in the African rift. There are ongoing initiatives to integrate paleoenvironmental and paleoanthropological data to understand the environmental context of hominid evolution. These include the International Continental Scientific Drilling Program (ICDP)- and NSF-sponsored Hominid Sites and Paleolakes Drilling Project (HSPDP, http://www.icdp-online.org/front_content. php?idcat=1225); new initiatives to investigate the fundamental processes underpinning rift initiation and evolution (e.g., GeoPRISMS, http://www.geoprisms.org/); and new observational and climate modeling efforts to understand East African climate history. Workshop participants reviewed past studies and current initiatives to define scientific goals and priorities in the critical areas of East African paleoclimate, rifting processes, and ecosystem evolution. We then reviewed the stratigraphic architecture and environmental history of Lake Turkana, Lake Albert, and Lake Tanganyika to evaluate their potential for addressing key scientific questions in order to develop a strategic plan for drilling projects in the East African lakes.

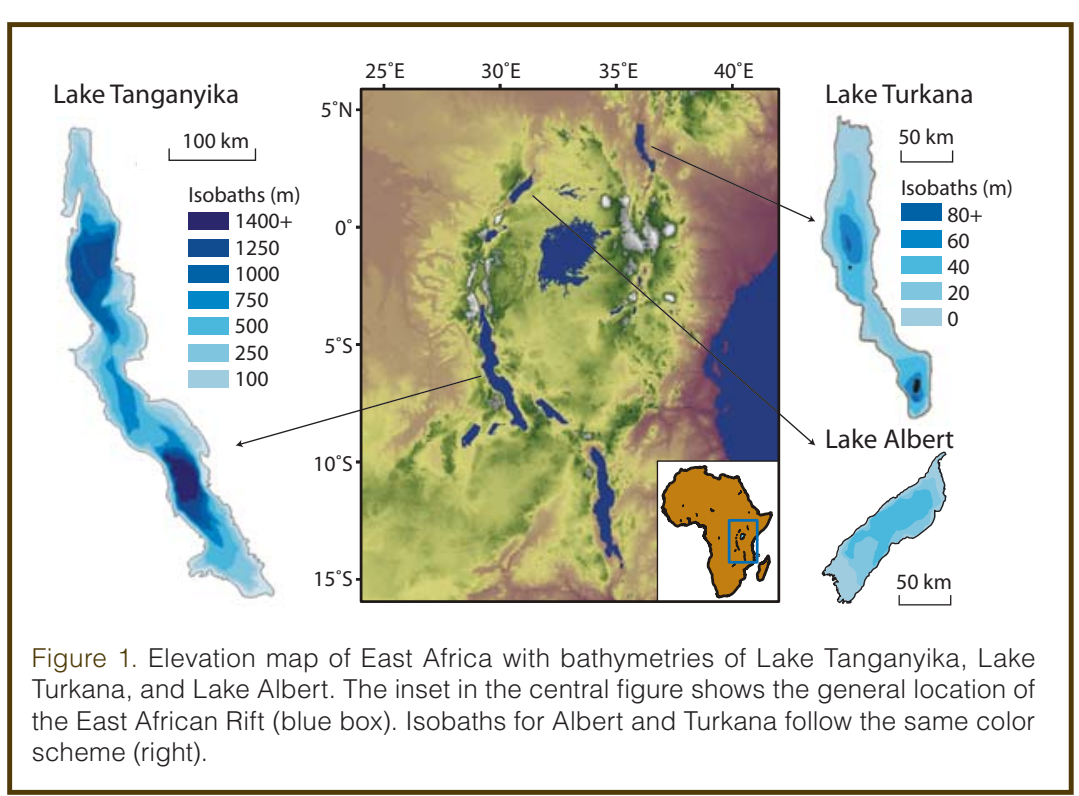

\section{Plio-Pleistocene East African Climate}

Decades of research have provided us with a relatively coherent picture of climate change at the high latitudes during late Cenozoic time, including iconic marine sedimentary records and ice cores that document glacial-interglacial variability and abrupt, millennial climate change (Fig. 2). Unfortunately, our understanding of tropical climate systems, and particularly continental tropical climate, lags far behind our knowledge of the high latitudes. Only recently we thought that African climate marched largely to the beat of the northern high-latitude ice sheets, yet drill cores recovered by the Lake Malawi drilling project revealed the existence of major droughts in Southeast Africa, far exceed- 
ing the aridity experienced during the Last Glacial Maximum, prior to 75,000 years ago (Scholz et al., 2007). These droughts appear to have been forced by eccentricity modulation of orbital precession, and they possibly affected the dispersal of anatomically modern humans both within and out of Africa (Blome et al., 2012). Still, the Malawi drill cores cover only the latter part of the Pleistocene and record climate history at the southernmost end of the African rifta climate setting that differs considerably from the rest of the rift to the north. Recent modeling studies have suggested strong linkages between Plio-Pleistocene changes in the sea-surface temperature structure of the tropical Pacific and Indian Oceans and changes in East African rainfall (Brierley and Fedorov, 2010), potentially affecting the evolution of our species. These new perspectives call into question many of the fundamental mechanisms and processes causing African climate variability, including the following. Are megadroughts present at sites to the north, and are they antiphased in their timing relative to those in Malawi as predicted by the precessional insolation forcing model? How consistent is the relationship between precessional orbital forcing and East African climate through the Plio-Pleistocene?

Numerous outcrop and marine sediment records from tropical East Africa suggest that East African climate has responded to a complex and interrelated set of climate forcings. These include orbitally-driven changes in insolation, changes in global ice volume and atmospheric greenhouse gas concentrations, long-term reorganizations of the principal modes of sea-surface temperature variability such as El Niño-Southern Oscillation (ENSO), and tectonically-driven changes in oceanic and atmospheric circulation (Scholz et al., 2007; Tierney et al., 2008; Brierley and Fedorov, 2010). Understanding the governing mechanisms and sensitivity of African climate to these phenomena will require long and continuous climate records extending into at least the Pliocene to observe East African climate responses across multiple events and time scales. Moreover, the Pliocene offers the most recent extended warm period, when atmospheric greenhouse gases approached values similar to those we will witness in the near future, and when continental configurations were similar to those today (Committee on the Earth System Context for Hominin Evolution, 2010). Workshop participants high- lighted that such records will allow us, for the first time, to address various questions:

- What are the dynamics of late Miocene-Pleistocene (last $7 \mathrm{Myr}$ ) African climate as a consequence of the mid-Pliocene termination of a permanent El Niño, ocean circulation change with the closure of the Indonesian seaway, the onset, intensification, and changes in the periodicity of Northern Hemisphere Glaciation, and the development of and interactions with East African Rift topography?

- What is the sensitivity and spatial variability of East African hydrology and temperature to orbital-scale climate forcings? Are tropical air temperature and hydrologic change coupled through time, and what are their sensitivities to radiative forcing from greenhouse gases and seasonal insolation?

- How do the rates and amplitudes of East African climate change on millennial to decadal time scales vary as a function of mean climate state? What are the mechanisms underpinning this time scale of variability?

Fundamentally, our goal is to understand the PlioPleistocene climate evolution of Africa at a resolution com-
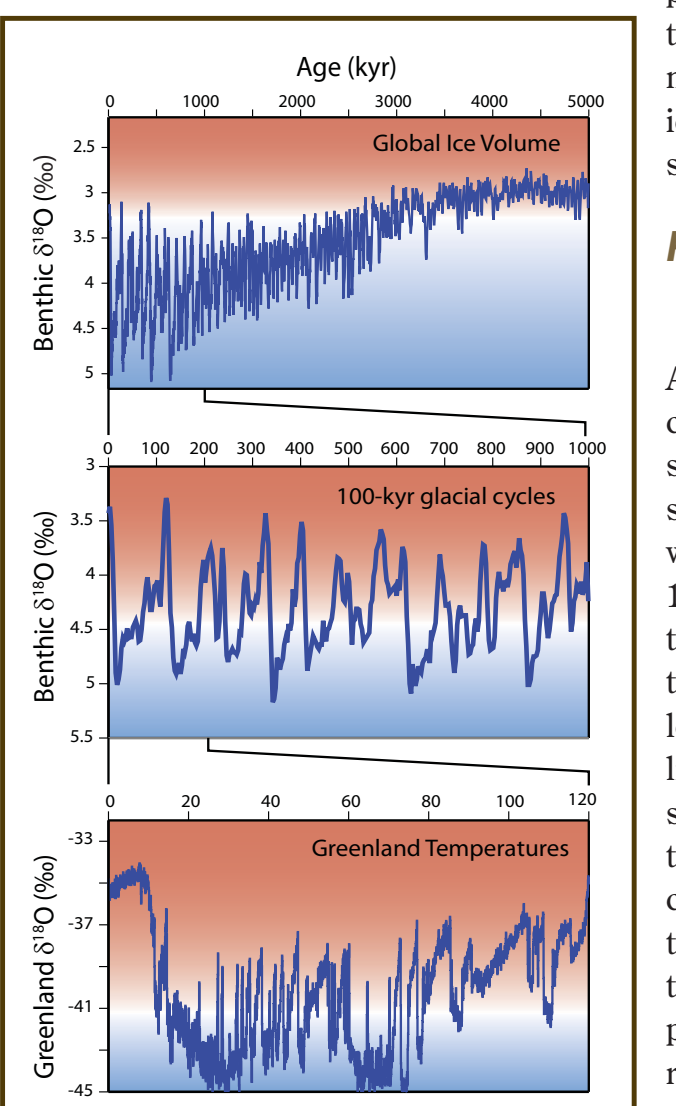

Figure 2. Climate change at different time scales as indicated by marine foraminiferal benthic oxygen isotopic data (Liesecki and Raymo, 2005) and oxygen isotopic reconstructions of Greenland temperatures (Members North Greenland Ice Core Project, 2004) parable to the records of climate from the high latitudes (Fig. 2), providing key new insights into the dynamics of tropical continental rainfall variability and sensitivity.

\section{Rift Initiation and Evolution}

The general notion is that the East African Rift formed as heat flow from the convecting mantle weakened the lithosphere and allowed the African Plate to stretch and fracture along pre-existing weaknesses in the lithosphere (Ebinger, 1989). This, coupled with the introduction of magma in at least some parts of the rift, led to rapid deformation and localization of strain along pre-existing lithospheric structures. However, these simple conceptual models fail to explain the rates and complexity of rifting processes, and the relative roles of magmatism, volatiles, and pre-existing structures in the rifting process are very poorly known. Both magmatism and reactivation of pre-existing structures can help to explain rift initiation and lithospheric stretching (Dunbar and Sawyer, 1989; Buck, 2004), given the relatively weak forces involved in extensional plate tectonics, whereas volatiles 
such as $\mathrm{H}_{2} \mathrm{O}$ and $\mathrm{CO}_{2}$ can further accelerate fault movement through their effects on the melting point of mantle solids,pore pressures, and metasomatism (Floyd et al., 2001). Magmatism and volatile content also likely play a key role in regulating the movement of faults and associated long-term fault slip rates. Investigation of the volatile contents in drill core pore waters, downhole heat gradients, tephrastratigraphy, and the frequency of seismically-triggered sedimentary events could all shed light on these issues.

We have a limited understanding of the intertwined processes of rift tectonics, magmatism, erosion, and sedimentation and their evolution in space and time, as in today's rift basins we thus far see only the end products of processes integrated over millions of years. For instance, the evolution of elevated rift flanks has a large impact on regional rainfall and erosion and interacts with the large-scale monsoon circulation over East Africa. Eroded sediment, in turn, may substantially impact the rifting processes and architecture (Spiegel et al., 2007).

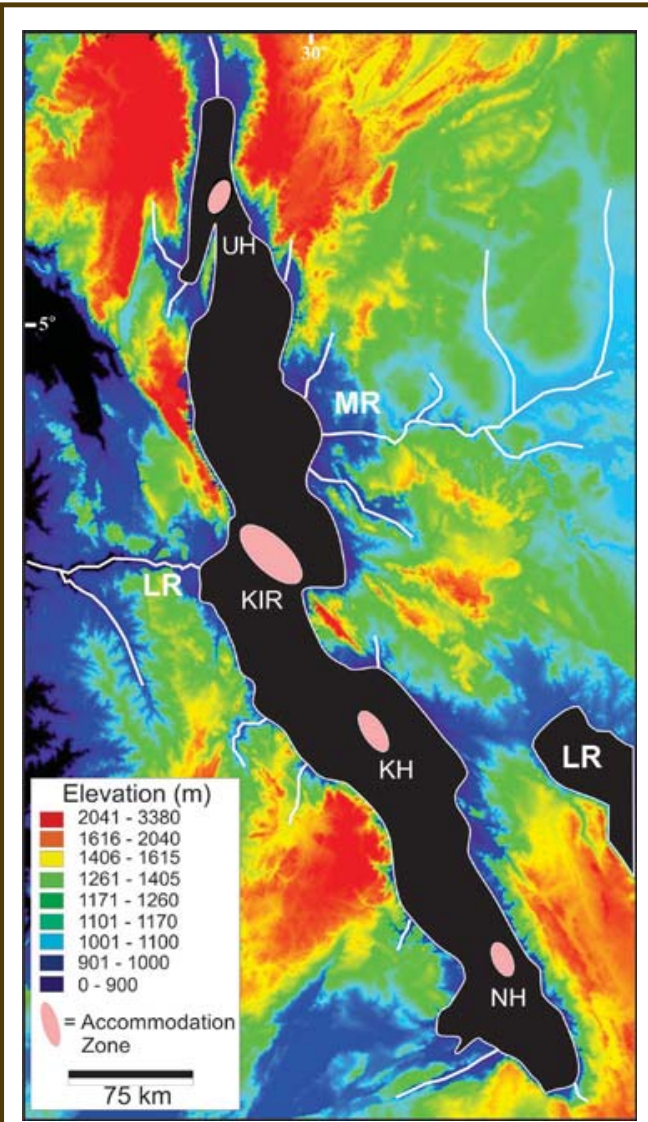

Figure 3. Digital elevation model of the Tanganyika basin showing the location of submerged high-relief accommodation zones within the lake. UH=Ubwari horst, $\mathrm{KIR}=$ Kavala Island Ridge, $\mathrm{KH}=$ Kalya horst, and $\mathrm{NH}=$ Nitiri High. At left, LR=Lukuga River, Tanganyika's outlet. At right, $L R=L a k e$ Rukwa, and MR=Malagarasi River. Modified from McGlue et al. (2008)

\section{Human, Floral, and Faunal Evolution}

The East African Rift lakes harbor some of the best examples of explosive speciation on the planet (Martens, 1997). Best-known are East Africa's cichlid fishes, which have evolved into groups of literally hundreds of endemic fishes in Lake Tanganyika, Lake Malawi, and Lake Victoria; however, these lakes also contain highly diverse endemic groups of snails, diatoms, ostracodes, and crabs. Tools of molecular genetics now allow for analysis of DNA preserved in fossils of many of these groups, potentially allowing the reconstruction of the genetic history of entire species, from evolution to (in some cases) extinction. Moreover, the East African Rift houses the fossil record of our own lineage and contains some of the most extensive dryland biomes on Earth. Nowhere else can lacustrine scientific drilling provide such fundamentally important insight into the coupling between environmental change and biological evolution (Martens, 1997), including the evolution of Homo sapiens (Commiittee on the Earth System Context for Hominin Evolution, 2010).
Addressing these issues will require detailed, multidisciplinary analyses of rift basins and their sediments, and they reflect key initiatives within the GeoPRISMS program (Morgan et al., 2011).

In particular, drill cores could help to evaluate the following three important factors:

- the rates of border fault slip in the rift basins, and how they are constrained by geothermal gradients and volatile concentrations;

- the relationships between long-term fault slip rates and short-term seismic hazards such as earthquake recurrence; and

- long-term erosion rates, sediment budgets and accumulation, and their temporal variability to help to constrain rates of crustal cycling.

Addressing these issues will require investigation of rift evolution in space and time, coupling drill core analyses with detailed seismic stratigraphic surveys, thermochronologic studies of landscape evolution, and studies of erosion and deposition in present-day lakes.
Lake drill cores can provide more than simply the climate and environmental background in which new species evolve. The rich fossil records preserved in many rift basins could be used to address the rates of change, linearity, and sensitivity of the evolution of species as well as ecosystems and ecosystem processes. Such work would involve a nested approach to identify time scale dependence of ecological and evolutionary responses.

Drilling of extant lakes such as Tanganyika, Turkana, and Albert would dovetail extremely well with the HSPDP, which will provide new drill core from multiple paleolake basins in East Africa, each spanning several hundred thousand years to target key intervals of hominin evolution. These new cores will provide valuable records of environmental variation at hominin sites with direct links to fossil-bearing outcrops; however, these records will be spatially and temporally discontinuous. Long and relatively continuous lacustrine sedimentary records spanning the Plio-Pleistocene, such as what we could obtain from Africa's extant great lakes, would provide a climatic framework in which to interpret the shorter HSPDP records. While marine sedimentary records could further augment this broader context, ongoing piracy in the western Indian Ocean unfortunately constrains 
marine coring in this region. Drill core from Lake Tanganyika, Lake Turkana, and/or Lake Albert could thus prove instrumental to studies of the climatic context of hominin evolution (Committee on the Earth System Context for Hominin Evolution, 2010).

\section{Study Sites and Target Selection}

Sedimentary records exist in Lake Tanganyika, Lake Turkana, and Lake Albert to answer these questions, but each lake affords very different temporal windows on past climate, different styles of rifting, and different opportunities for understanding evolutionary biology. Moreover, each lake offers very different opportunities in terms of their time scale, resolution, and continuity.

\section{Lake Tanganyika}

Tanganyika $\left(32,600 \mathrm{~km}^{2}, 1471 \mathrm{~m}\right.$ deep) is the largest, oldest, and deepest lake in East Africa, with an estimated age of 9-12 Ma (Cohen et al., 1993). Tanganyika is one of the most biodiverse lakes on Earth, hosting endemic cichlid fish, snails, ostracods, crabs, and other organisms, and it lies within the vast but poorly understood Miombo woodland ecosystem of SE tropical Africa. Tanganyika is comprised of four major sub-basins separated by deep-water horsts and provides very clear examples of rift segmentation, fault behavior, and structural growth that could greatly facilitate studies of fault behavior and seismicity. Although the Rungwe volcanic field to the south provides occasional tephras to Tanganyika, there is no extensive volcanism in the basin.

Tanganyika lies within the core path of the Intertropical Convergence Zone's migration over central Africa. Its late Quaternary climate history is largely out of phase with Lake Malawi, indicating that Tanganyika acts as a Northern Hemisphere site despite its location. Drill core data from Tanganyika will therefore complement, not replicate, studies

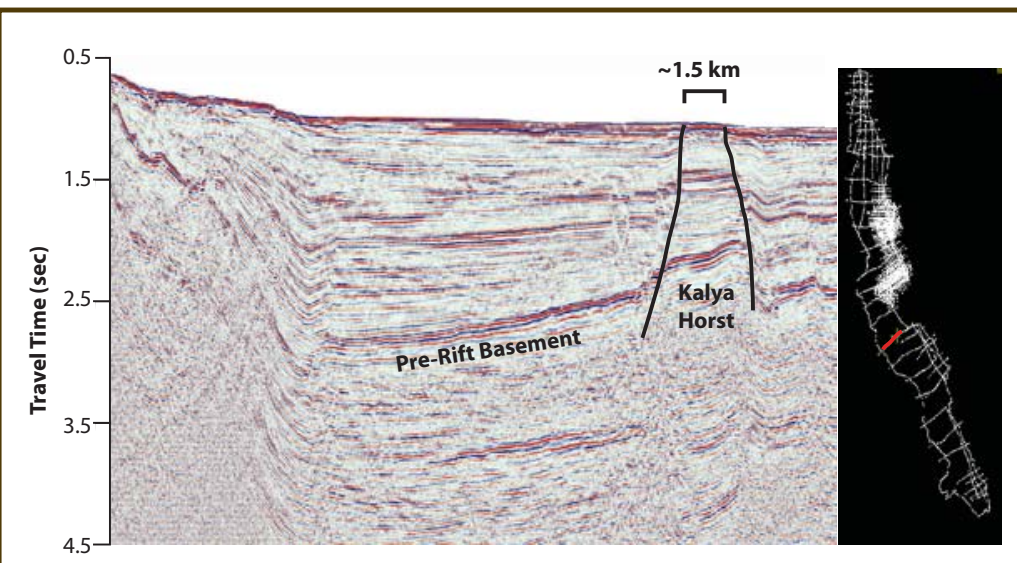

Figure 4. Seismic section from the northern end of the Kalya horst; location of the seismic section within Lake Tanganyika is illustrated by the red line within the seismic grid at right. Note the presence of a continuous and condensed sedimentary sequence above pre-rift basement on the Kalya horst, indicated by the bracket. Data are from Project PROBE (Rosendahl, 1988). in Lake Malawi. The proximity of both Tanganyika and Malawi to the Rungwe Volcano could facilitate inter-basin tephrstratigraphic studies. Moreover, recent work has demonstrated Tanganyika's potential to record climate processes at orbital, millennial, and even interannual time scales, as the sediments contain a wealth of climate proxies preserved in often laminated sediments (Cohen et al., 2006; Tierney et al., 2008, 2010). Most importantly, recent work has documented deep-water horst blocks (Fig. 3) with condensed sedimentary sequences (Fig. 4), putting early Pliocene-age sediment within relatively easily drilling depths at sites (McGlue et al., 2008). These sites are located at high-relief accommodation zones in deep enough water to have continuous deposition over much, if not the entirety, of this time. The Kalya and Nitiri horsts in Tanganyika's southern basin, in particular, lie in deep water below the depth of maximum lake lowstands and appear to house long and continuous sedimentary sections (McGlue et al., 2008; Fig. 4).

While the challenges and cost of drilling a long hole in deep water (500 $\mathrm{m}$ of mud in $700 \mathrm{~m}$ of water, for instance) are considerable, the group felt that drilling Tanganyika presented the most exciting scientific opportunities of any African lake. Tanganyika's deep-water horsts are perhaps the only depositional setting in East Africa likely to contain continuous Pliocene-present sediments at easy drilling depth. The potential significance of a continuous, high-resolution, Pliocene-present sediment record for tropical paleoclimatology, paleoanthropology, evolutionary biology, and rifting processes far outweighs the significant time and investment required to move the Tanganyika record forward.

\section{Lake Turkana}

Rifting and volcanism have affected the Turkana basin since the Oligocene, with the modern lake developing in the Pliocene. Turkana is well-known for its complex rifting history, and it has extensive and remarkable facies architecture (clastic/carbonate sequences) that house worldfamous vertebrate and hominin fossil locales. However, the rifting processes in Turkana are the most complex of the three lakes, and there are extensive and relatively young basalts that may resurface parts of the Turkana basin. The modern aquatic biota is relatively depauperate, but drilling in Turkana could dovetail with planned drilling of early Pleistocene lake beds in west Turkana as part of HSPDP and provide the most direct linkage to paleoanthropology of the three lakes.

Lake Turkana is East Africa's northernmost rift lake, and its sediments could provide important insight into the climate of northeastern Africa that would strongly complement recent drilling efforts on Lake Malawi. Turkana is extremely sensitive to climate variability, and this is reflected in the lake's 
sedimentary record (Halfman et al., 1994). Moreover, there is a well-established tephrastratigraphy for Turkana that would aid in developing age models for drill cores. However, the modern lake is characterized by very high sedimentation rates, and the lake is certain to have undergone desiccation events that were likely associated with basin deflation. Moreover, on long time scales the complex paleogeography and rift history could complicate paleoclimate reconstruction. To further complicate matters, available seismic reflection data from Turkana are rather poor, requiring significant efforts to properly locate drilling targets. Some aspects of drilling logistics in Turkana are relatively simple, but the remote location, high winds, and lack of facilities will make Turkana a logistically challenging target.

In sum, Turkana presents many exciting and extremely valuable opportunities, particularly the development of a high-resolution climate record

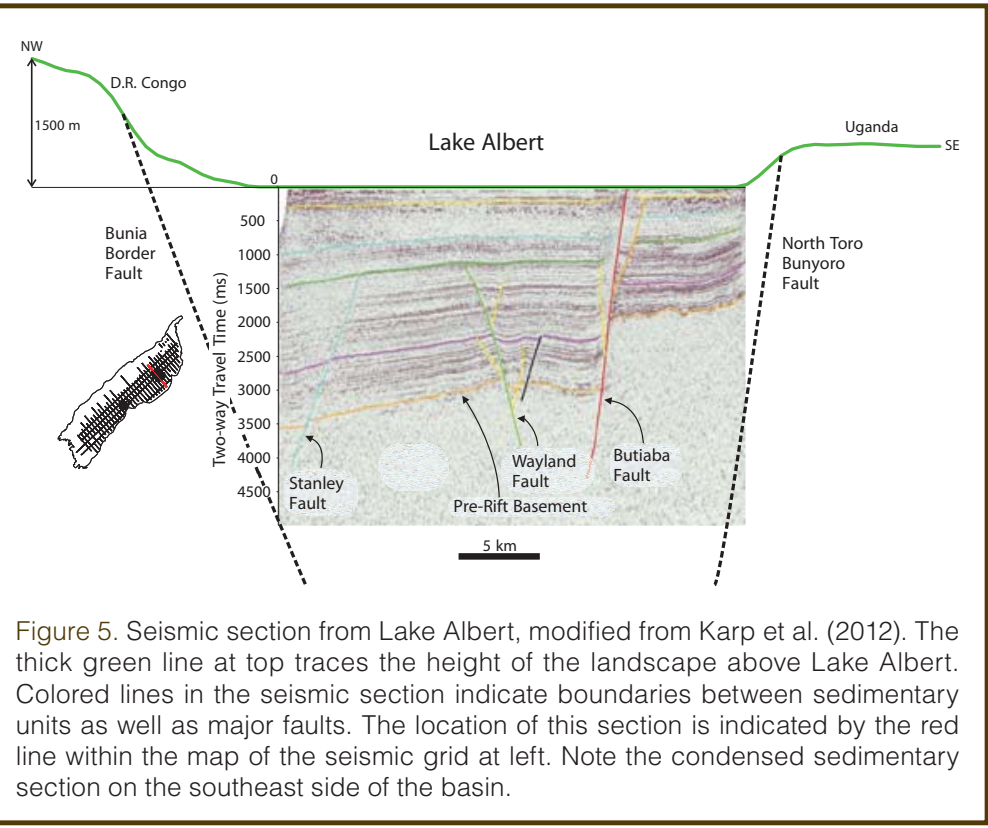
spanning the late Pleistocene at the northern end of the East African Rift and in a site of paleoanthropologic importance. Yet, the complications posed by high sedimentation rates, hiatuses, and a complex rifting history make Turkana a lower priority than Tanganyika.

\section{Lake Albert}

Lake Albert is situated near the equator in the western arm of the East African Rift. The basin contains, in places, several kilometers of lacustrine and fluviolacustrine sediments that extend into the Miocene (Fig. 5), with considerable outcrop exposures that have been investigated for their fossil content and paleobiology. Drilling in Lake Albert could elucidate how rift-generated topography and the uplift of the Rwenzori Mountains control sedimentation and rift catchments, and it could further elucidate the history of the source of the White Nile River. Moreover, the Albertine Rift is in many ways simpler than Tanganyika and Turkana, facilitating studies of rifting processes. Drilling in Lake Albert could provide incredibly valuable new records of the late Miocene to present evolution of East African climate. However, discontinuities existing even in late glacial sediments indicate the likelihood of numerous hiatuses in longer drill core records when climate fluctuation may be more extreme.

Perhaps the strongest argument for drilling Albert lies in the extensive infrastructure related to recent oil discoveries in the Albert basin by Tullow Oil, plc (http://www.tullowoil. com). There is an exquisite seismic-stratigraphic framework for Lake Albert, and drilling infrastructure is already available in the basin. Lake Albert is the main depositional sump for much of central equatorial Africa, including Lake Victoria and Lake Edward, and could therefore provide an unparalleled but discontinuous record. Given the likelihood of discontinuities in drill core data, Lake Albert was prioritized beneath Tanganyika, but given Albert's extraordinary

record and the near certainty of future industrial drilling activities, the group felt that we should work to partner with industry in drilling activities, perhaps through onshore drilling where condensed sections are present (Fig. 5).

\section{Summary and Future Work}

Scientific drilling in Lake Tanganyika, Lake Turkana, and Lake Albert can answer fundamentally important questions concerning tropical climate variability and change, rifting processes, paleobiology, and human evolution. Among these lakes, Tanganyika stands out as an extraordinary opportunity due to the presence of continuous, deep-water sedimentary records spanning the Pliocene to present, as well as being the nexus of interest in the lake basin for paleoclimatologists, seismologists, and evolutionary biologists. Workshop participants were uniquely enthusiastic about moving forward, and they agreed on several benchmarks to begin a continental drilling project on that lake.

First, and most importantly, existing seismic reflection data from Tanganyika is of very high quality but low spatial resolution. Beach Energy (Adelaide, South Australia) will acquire new deep seismic reflection data from Tanganyika's southern basin, which contains the best drilling targets on deep-water horst environments, and the company could make sections of this data available. These data will provide an excellent seismic-stratigraphic framework for interpreting drill core records but is unlikely to have the resolution needed to detect small-scale unconformities and site drilling sites. The group agreed that our first step should be a proposal to acquire high-resolution data and shallow piston cores over deep-water horsts in Tanganyika's southern basin to determine appropriate drilling targets and identify major sedimentary facies likely to be encountered in scientific drilling. 
Secondly, the group expressed interest in accessing extensive existing shallow core collections from Tanganyika, metadata on which is not widely accessible. The group agreed that we would make information about these cores accessible through LacCore (http://1rc.geo.umn.edu), University of Minnesota, to allow for sample analysis, testing, and proxy calibration and to expand the science team involved in Tanganyika drilling.

Finally, there were several more specific studies that could complement a Tanganyika drilling project, ranging from tephrastratigraphic studies of the Rungwe volcanics to limnological studies in the Tanganyika basin. The group agreed to pursue these through PI-driven proposals to relevant science agencies, with coordination and data sharing to build the Tanganyika drilling program.

\section{References}

Blome, M., Cohen, A.S., Tryon, C.A., Brooks, A.S., and Russell, J., 2012. The environmental context for the origins of modern human diversity: A synthesis of regional variability in African climate 150,000-30,000 years ago. J. Hum. Evol., 62(5):563-592. doi: 10.1016/j.jhevol.2012.01.011

Brierley, C.M., and Fedorov, A.V., 2010. Relative importance of meridional and zonal sea surface temperature gradients for the onset of the ice ages and Plio-Pleistocene climate evolution. Paleoceanography, 25: PA2214:. doi:10.1029/2009PA001809

Buck, W.R., 2004. Consequences of aesthenosperic variability on continental rifting. In Karner, G.D., Taylor, B., Driscoll, N.W., and Kohlstedt, D.L. (Eds.), Rheology and Deformation of the Lithosphere at Continental Margins: New York (Columbia University Press), 1-30.

Cohen, A.S., Lezzar, K.E., Cole, J., Dettman, D.L., Ellis, G.S., Eagle, M., Chorokoa, K., et al., 2006. Late Holocene linkages between decade-scale climate variability and productivity at Lake Tanganyika, Africa. J. Paleolimnol., 36(2):189-209. doi:10.1007/s10933-006-9004-y

Cohen, A.S., Soreghan, M., and Scholz, C., 1993. Estimating the age of formation of lakes: An example from Lake Tanganyika, East African rift system. Geology, 21:511-514. doi:10.1130/0091-7613(1993)021<0511:ETAOFO >2.3.CO;2

Committee on the Earth System Context for Hominin Evolution, 2010. Understanding Climate's Influence on Human Evolution, Washington, DC (The National Academies Press).

Dunbar, J.A., and Sawyer, D.S., 1989. How preexisting weaknesses control the style of continental breakup. J. Geophys. Res., 94:527-530. doi:10.1029/JB094iB06p07278

Ebinger, C.J., 1989. Tectonic development of the western branch of the East African rift system. GSA Bull., 101:117-133. doi:10.1130/0016-7606(1989)101<0885:TDOTWB >2.3.CO;2

Floyd, J.S., Mutter, J.C., Goodliffe, A.M., and Taylor B., 2001. Evidence for fault weakness and fluid flow within an active low-angle normal fault. Nature, 411:779-783. doi:10.1038/35081040

Halfman, J.D., Johnson, T.C., and Finney, B., 1994. New AMS dates, stratigraphic correlations and decadal climatic cycles for the past $4 \mathrm{ka}$ at Lake Turkana, Kenya. Palaeogeogr. Palaeoclimatol. Palaeoecol., 111:83-98. doi:10.1016/
0031-0182(94)90349-2

Karp, T., Scholz, C.A., and McGlue, M.M., 2012. Structure and stratigraphy of the Lake Albert Rift, East Africa: Observations from seismic reflection and gravity data. In Bartov, Y., and Nummedal, D. (Eds.), Sandstones in Lacustrine Depositional Settings, AAPG Memoir 95, in press.

Liesecki, L., and Raymo, M., 2005. A Plio-Pleistocene stack of 57 globally distributed benthic $\delta^{18} \mathrm{O}$ records. Paleoceanography, 20:PA1003. doi:10.1029/2004PA001071

Martens, K., 1997. Speciation in ancient lakes. Trends Ecol. Evol., 12:177-182. doi:10.1016/S0169-5347(97)01039-2

McGlue, M.M., Lezzar, K.E., Cohen, A.S., Russell, J.M., Tiercelin, J.J., Felton, A., Mbede, E., and Nkotagu, H., 2008. Seismic records of late Pleistocene aridity in Lake Tanganyika, tropical East Africa. J. Paleolimnol., 40:635-653. doi:10.1007/ s10933-007-9187-x

Members North Greenland Ice Core Project, 2004. High-resolution record of the Northern Hemisphere climate extending into the last interglacial period. Nature, 431:147-151. doi: 10.1038 /nature 02805

Morgan, J., Arrowsmith, R., Benoit, M., Ebinger, C.J., Fischer, T., Flemings, P., Keranen, K., et al., 2011. GeoPRISMS Rift Initiation and Evolution Plan. http://www.geoprisms.org/ rie.html

Rosendahl, B.R., 1988. Seismic Atlas of Lake Tanganyika, East Africa: Durham, North Carolina, USA (Project PROBE Geophysical Atlas Series, Duke University).

Scholz, C., Johnson, T.C., Cohen, A.S., King, J.W., Peck, J.A., Overpeck, J.T., Talbot, M.R., et al., 2007. East African megadroughts between 135 and 75 thousand years ago and bearings on early-modern human origins. Proc. Natl. Acad. Sci. U.S.A., 42:16416-16421. doi:10.1073/pnas.0703874104

Spiegel, C., Kohn, B.P., Belton, B.X., and Gleadow, A.J.W., 2007. Morphotectonic evolution of the central Kenya rift flanks: Implications for late Cenozoic environmental change in East Africa. Geology, 35:427-430. doi:10.1130/G23108A.1

Tierney, J.E., Mayes, M., Meyer, N., Johnson, C., Swarzenski, P.W., Cohen, A.S., and Russell, J.M., 2010. Late-twentieth-century warming in Lake Tanganyika unprecedented since AD 500. Nature Geoscience, 3:422-425. doi:10.1038/NGEO1865.

Tierney, J.E., Russell, J.M., Huang, Y., Sinninghe-Damste, J.S., Hopmans, E.C., and Cohen, A.S., 2008. Northern Hemisphere controls on tropical southeast African climate during the past 60,000 years. Science, 322(5899):252-255. doi:10.1126/science. 1160485

\section{Authors}

James M. Russell, Department of Geological Sciences, Brown University, 324 Brook Street, Box 1846, Providence, RI 02912-9019, U.S.A., e-mail: James_Russell@Brown.edu

Andrew S. Cohen, Department of Geosciences, University of Arizona, Gould-Simpson Building \#77, 1040 East 4th Street, Room 326, Tucson, AZ 85721-0001, U.S.A.

Thomas C. Johnson, Large Lakes Observatory, University of Minnesota Duluth, 2205 East 5th Street, Research Laboratory Building 204, Duluth, MN 55812-3024, U.S.A.

Christopher A. Scholz, The College of Arts and Sciences, Department of Earth Sciences, Syracuse University, 204 Heroy Geology Laboratory, Syracuse, NY 13244-1070, U.S.A. 